Cancer stem-like cells (CSLCS) are defined as cancer cells with stem cell characteristics. Although CSLCs constitute no more than a few percent of the tumor mass, they play important roles in cancer chemo-resistance, metastasis and disease recurrence. Ovarian cancer (OC) is considered the most aggressive gynecological malignancy in which the role of CSLCs is of major significance, although it remains to be specified. The studies describing ovarian CSLC phenotype vary in the definition of the molecular pattern of expression of the main markers such as CD133, CD44, CD117, and CD24. Stem-like features of $O C$ have been shown to correlate with the clinical course of the disease and permit diagnosis, prognosis and treatment outcome to be improved. Identification of CSLC markers could provide hallmarks which, related to the chemo-resistance of the disease, will facilitate treatment selection. This review describes recent advances in research on stem-like cell status in OC, mainly focusing on surface markers of CSLCS and their clinical relevance.

Key words: cancer stem-like cells, ovarian cancer, surface markers, prognosis.

Contemp Oncol (Pozn) 2018; 22 (1A): 48-55 DOI: https://doi.org/10.5114/wo.2018.73885

\section{Surface markers of cancer stem-like cells of ovarian cancer and their clinical relevance}

\author{
Aleksandra Klemba' ${ }^{1,2}$, J. Karolina Purzycka-Olewiecka ${ }^{1}$, Gabriel Wcisło ${ }^{1}$, \\ Anna M. Czarnecka ${ }^{1}$, Sławomir Lewicki ${ }^{3}$, Bogdan Lesyng ${ }^{4,5}$, Cezary Szczylik ${ }^{1,6,7}$, \\ Claudine Kieda ${ }^{1}$
}

${ }^{1}$ Department of Oncology, Military Institute of Medicine, Warsaw, Poland

${ }^{2}$ College of Inter-Faculty Individual Studies in Mathematics and Natural Sciences, University of Warsaw, Poland

${ }^{3}$ Department of Regenerative Medicine and Cell Biology, Military Institute of Hygiene and Epidemiology, Warsaw, Poland

${ }^{4}$ Faculty of Physics, University of Warsaw, Poland

${ }^{5}$ Bioinformatics Laboratory, Mossakowski Medical Research Institute, Polish Academy of Science, Poland

${ }^{6}$ European Health Centre, Otwock, Poland

${ }^{7}$ Medical University of Warsaw, Poland

\section{Introduction}

Ovarian cancer (OC) is the most lethal gynecological cancer, accounting for $4 \%$ of all cancer cases and $4.2 \%$ of deaths in women. It represents the sixth most frequently diagnosed cancer and seventh most common cause of death in females. Increased incidence of OC has been observed over the last 40 years in Poland [1]. Several issues of OC biology remain challenging, including the difficulty of diagnosis and treatment. More than $70 \%$ of OC cases are diagnosed in stage III and IV. Only $20 \%$ of patients with advanced OC survive more than 5 years; consequently $O C$ is a critical cause of gynecological cancer death [1]. It is estimated that 1 out of $70(1.4 \%)$ newborn females will develop OC. The highest prevalence of $\mathrm{OC}$ is in the 6 th decade of life and $1 \%$ of women will die from the disease [2].

Currently, decision making on how to treat OC is based on clinical and pathological variables such as age, stage, grade, histology, debulking status and response to chemotherapy. Molecular data on p53 status can provide new criteria for routine clinical assessment [3]. Mortality proves that the treatments require improvement since resistance to chemotherapy remains a challenge [4].

Since the initial experimental demonstration of the presence of cancer stem-like cells (CSLC) in OC, the concept has gained importance in order to explain OC aggressiveness [5, 6]. CSLCS possess the capacity for self-renewal and reproduction of whole tumor populations, and they show increased tumor initiating potential (TIC) [6]. Although these cells constitute a few percent of the tumor mass, they play a crucial role in cancer chemo-resistance, metastasis and tumor recurrence. Methods to isolate ovarian CSLCS are based on surface marker expression, dye efflux and increased clonogenicity. CSLCS show expression of undifferentiated stem cell markers such as NANOG, OCT4, NESTIN, ABCG2, and BMI1, and are able to differentiate in ovarian marker expressing cells. In vitro tests for their identification and function include self-renewal, anchorage-independent growth and ability to reproduce histological characteristics of the tumor. CSLCS also enhance tumor survival by epithelial-to-mesenchymal transition (EMT, e.g. blockade of p53-conferred apoptosis) [6]. The ovarian CSLC phenotype is highly variable and does not allow a strict pattern definition [7, 8]. Concomitantly, some of the markers used to isolate CSLCS were shown to correlate with clinical 
features, indicating their possible use for diagnosis and prognosis of OC [9].

This review presents a number of selected surface markers used in CSLC research, and their putative correspondence to the clinical characteristics of OC. Particular emphasis is placed on surface markers as potential prognostic factors and targets for future treatments.

\section{Surface markers and identification of ovarian cancer stem-like cells}

\section{CD133+}

CD133 (prominin-1), a pentaspan transmembrane 120 kDa glycoprotein, was initially shown to be a marker for hematopoietic stem and progenitor cells [10]. It was also found on several types of stem cells in adults and is believed to suppress differentiation [11]. In ovarian cancer, CD133 expression was first investigated by Ferradina and co-workers [12, 13], who showed that epitopes defined as CD133-1 and CD133-2 were more abundant in tumors than in normal ovary tissues and benign tumors. CD133+ OC cells showed higher clonogenic and proliferative potentials than CD133- cells [12]. Curley and coworkers showed that the CD133+ cells isolated from primary cancer were able to recapitulate the tumor characteristics in NOD/SCID mice [14].

CD133 expression in OC cells is epigenetically regulated by methylation $[15,16]$. CD133 is coexpressed with MUC4 on colony forming cells and side population cells [17]. Endothelin receptor-A (ETRA) - a molecule involved in cell migration, metastasis, and proliferation - plays an important role in CD133+ cells. ETRA was expressed on CD133+ cells isolated from primary OCs and OC cell lines and its inhibition decreased the percentage of CSLCS when induced by chemotherapy. Blockage of ETRA by chemotherapy decreased the ability of the cells to form spheres, which is a property of CSLCS [18]. In vitro inhibition of $\mathrm{NIH}$ :OVCAR5 CD133+ cells by dCD133KDEL (a CD133 inhibitor) selectively reduced the growth of $\mathrm{NIH}$ :OVCAR5-luc tumors in vivo [19]. Similar effects were observed in vitro for CCL5 chemokine and its receptors - CCR1, CCR3 and CCR5. They were upregulated in CD133+ CSLCS and their inhibition reduced cell aggressiveness [20]. The mechanism of action involves activation of the $\kappa \mathrm{B}$ nuclear factor (NF- $\mathrm{B})$ and increased expression of metalloproteinase-9 (MMP9) [20]. Moreover, IL-17 promoted self-renewal of CD133+ CSLCs, mediated by NF- $\mathrm{BB}$ and p38 MAPK signaling pathways [21].

OVCAR-3 cells displayed a set of aberrantly expressed miRNAs (miR-204, miR-206, miR-100, miR-200c, miR223) in both CD133+ and CD133- cells [22]. Further studies showed that the level of miR-200a was decreased in CD133-1+ cells compared to CD133-1-. Overexpression of miR-200a in CD133/1+ decreased their migration and invasion. It also decreased and suppressed ZEB2 expression [23]. CD133+ spheroid forming OVCAR3 cells displayed upregulated levels of miR-205, miR-146a, miR-200a, miR200b, and miR-3 and downregulated the levels of miR-1201 and miR-1181 [24]. Expression of Sox2, Nanog, and Oct3/4 was higher in CD133+ than in CD133- cells [21]. This series of evidence points to CD133 as a stemness marker.
The CD133+ cells are also thought to maintain ovarian yolk sac tumor [25]. When NOY1 cells (yolk sac tumor cell line) were co-cultured with peritoneal mesothelial cells they displayed increased CD133 expression accompanied by increased colony formation, migration and invasion. Those effects were reduced by the CXCR4 blocker AMD3100 [26].

Although CD133 was historically the first investigated stem cell surface marker and its study in OC provided substantial insight into OC progression, its mechanism of action remains elusive and it is not the only marker associated with stem-like features of OC cells.

\section{CD44}

CD44 is an integral membrane glycoprotein and the main receptor for hyaluronate $(\mathrm{HA})$. It participates in specific cell-cell and cell-extracellular matrix interactions and its presence is often correlated with resistance to chemotherapy and tumor progression $[27,28]$. The mechanism of CD44 action in OC includes interaction with hyaluronic acid (HA) leading to Nanog-Stat-3 activation [28]. Targeting of CD44 by CD44 siRNA together with paclitaxel delivery through a nanoscale based drug delivery system induced cell death and decreased the tumor without side effects [29]. A decrease in the CD44+ CSLC population was also obtained by using fusions cells (of dendritic cells and OC initiating cells), which were able to activate cytotoxic $T$ lymphocytes [30].

The combination of CD44 identification with other molecules makes CD44 a potential marker of CSLCS of OC.

\section{CD44/CD117}

The potential for CD44 along with CD117 to be a marker of epithelial ovarian stem-like cells was shown by the ability of CD44+/CD117+ cells to recapitulate the original tumor in vivo [8]. The TGF- $\beta$ mediated induction tissue transglutaminase (TG2) increases the population of CD44+/CD117+ cells [31]. Upon repeated treatments with low doses of cisplatin, a population of SKOV3 cells displayed an increase of CD44, CD117 and ALDH1 expression along with features of EMT, sphere formation ability, increased motility and multidrug resistance. SKOV3 cells also exhibited higher mitochondrial mass and upregulation of cytochrome C. The survival-promoting mitochondrial complex of hexokinase-II and the voltage-dependent anion channel are an efficient target for treatment [32]. Similarly to CD133+, the CD44 and CD117 expression on SKOV3 stem cells decreased upon overexpression of miR-200c together with the stem-like properties [33].

\section{CD44/MyD88}

Myeloid differentiation primary response gene 88 (MyD88) is a member of the toll-like receptor (TLR) family and contributes to the inflammatory microenvironment in OC [34]. CD44+/MyD88+ cells isolated from ascites and tumors from epithelial OC patients presented stem-like characteristics, including constitutive NF- $\mathrm{KB}$ activity, production of cytokines and chemokines (e.g. IL-1 $\beta$, IL-6, IL-8, MCP-1 and GRO $\alpha$ ), high capacity for tumor reconstitution, 
resistance to chemotherapeutics, blocking of TNF- $\alpha$-conferred apoptosis, capacity to form spheroids and ability to reinitiate the parental tumor in vivo [7]. They react with the isoflavone derivative NV-128 through mitochondrial reaction. Depression of mitochondrial function leads to a cytostatic effect via: (a) the AMPK $\alpha 1$ pathway resulting in mTOR inhibition; and (b) the mitochondrial MAP/ERK kinase/extracellular signal-regulated kinase pathway leading to membrane potential loss [35]. The CD44+/MyD88+ phenotype was shown to correlate with the TLR2-MyD88NFkappaB pro-inflammatory pathway and an increased load of cancer stem-like cells in OC [36].

\section{CD44/E-cadherin/CD34}

Presence of CD44, lack of E-cadherin and CD34 (phenotype CD44+/E-cadherin-/CD34-) marked OC cells (termed type I EOC cells) with the ability to recapitulate the tumor in vivo and participate in neovascularization [37]. These cells were further characterized by their low levels of miR-
199 and miR-214, in contrast to the type II (CD44-) OC cells. These microRNAs are regulated on pri-miR-199a2, which is controlled by TWIST-1. This suggested that TWIST-1 is a "stemness" regulator in some ovarian cells [37]. TWIST-1 was found to be constitutively degraded in stem-like cells of OC; therefore additional signals are required to trigger differentiation [38].

\section{CD44/CD24/Epcam}

Epithelial cell adhesion molecule, EpCAM, is overexpressed in several types of cancer cells [39]. The combination of three markers (out of 95) CD44+/CD24+/EpCAM+ allowed typing of cells displaying a shorter tumor-free period in vivo and increased migration and invasion characteristics in vitro. This population could be decreased (Table 2) [39]. Additionally E-cadherin-- cells selectively expressed LIN28, which colocalized with the CD44+/CD24+/ Epcam+ markers in the OVCAR-5 cell line, and was highly expressed in transgenic murine models of OC [40].

Table 1. Association of surface markers' presence with clinicopathological features and prognosis of ovarian cancer

\begin{tabular}{|c|c|c|c|c|}
\hline Marker & Method & Association & Sample size & Reference \\
\hline CD133 & $\begin{array}{l}\text { Fluorescent activated } \\
\text { cell sorting of CD113-1 } \\
\text { and }-2\end{array}$ & No correspondence with clinicopathological features & $41 \mathrm{OC}$ & {$[12]$} \\
\hline CD133 & Immunohistochemistry & $\begin{array}{l}50 \text { CD } 133+O C \\
\text { No prognostic information }\end{array}$ & $\begin{array}{l}160 \text { stage III, } \\
\text { IV OC }\end{array}$ & [13] \\
\hline $\begin{array}{l}\text { CD133/ } \\
\text { ALDH1 }\end{array}$ & $\begin{array}{l}\text { Tissue microarray, } \\
\text { immunofluorescence }\end{array}$ & $\begin{array}{l}\text { Expression of both markers was correlated with: } \\
\text { reduced DFS and OS }\end{array}$ & 56 stage III, IV OC & [51] \\
\hline $\begin{array}{l}\text { CD133/ } \\
\text { ALDH1 }\end{array}$ & Immunohistochemistry & $\begin{array}{l}\text { CD133+: } 49.1 \% \text { pOC/33.9\% rOC } \\
\text { ADLH1+: } 37.5 \% \text { pOC } 36.6 \% \text {. rOC } \\
\text { Coexpression: } 33.9 \% \text { pOC and } 36.6 \% \text { of rOC } \\
\text { CD133+ patients: } \\
\text { FIGO III/IV }(p<0.0001) \\
\text { worse PFI }(p=0.04) \\
\text { worse OS ( } p=0.02) \\
\text { CD133/ALDH1 coexpression in pOC was independent prognostic } \\
\text { factor of PFI and OS } \\
\text { No correlation between CSC and BRCA status }\end{array}$ & $\begin{array}{l}224 \text { paired } \\
\text { (primary and } \\
\text { recurrent) high } \\
\text { grade serous OC }\end{array}$ & {$[62]$} \\
\hline CD133 & Tissue microarray & $\begin{array}{l}\text { Expression in } 31 \% \text { of cancers } \\
\text { Expression associated with: } \\
\text { high-grade serous carcinoma }(p=0.035) \\
\text { late-stage disease }(p<0.001) \\
\text { ascites level }(p=0.010) \\
\text { non-response to chemotherapy }(p=0.023) \\
\text { shorter OS ( } p=0.007) \\
\text { shorter DFS ( } p<0.001) \\
\text { CD133 expression was an independent predictor of: } \\
\text { shorter DFS ( } p=0.024) \text {. }\end{array}$ & $400 \mathrm{OC}$ & {$[64]$} \\
\hline $\begin{array}{l}\text { CD133/ } \\
\text { CD117 }\end{array}$ & Immunohistochemistry & $\begin{array}{l}\text { CD133high = shorter DFS and OS } \\
\text { CD117 = shorter DFS }\end{array}$ & 64 serous $\mathrm{OC}$ & {$[54]$} \\
\hline $\begin{array}{l}\text { Nestin, } \\
\text { but } \\
\text { not } \\
\text { CD133 }\end{array}$ & Immunohistochemistry & $\begin{array}{l}\text { Nestin + correlated with: } \\
\text { cisplatin chemotherapy resistance ( } 55.0 \% \text { vs. } 20.1 \%, p=0.001) \\
\text { shorter OS ( } p=0.001) \\
\text { Nestin }=\text { independent predictor of shorter OS (HR }=2.501 \text {, } \\
p=0.007)\end{array}$ & $\begin{array}{l}123 \text { stage III and } \\
\text { IV serous OC }\end{array}$ & [58] \\
\hline $\begin{array}{l}\text { ALDH1, } \\
\text { Indirect } \\
\text { CD44 }\end{array}$ & $\begin{array}{l}\text { Immunohistochemical } \\
\text { staining }\end{array}$ & $\begin{array}{l}\text { ALDH1high ( }>50 \%) \text { : } \\
\text { poor OS }(p=0.004) \\
\text { higher ratio of death }(2.43,95 \% \mathrm{Cl}: 1.12-5.28) \\
\text { ALDH1 expression correlated with CD } 44 \text { expression }\end{array}$ & $84 \mathrm{OC}$ & {$[46]$} \\
\hline
\end{tabular}


Table 1. cont.

\begin{tabular}{|c|c|c|c|c|}
\hline Marker & Method & Association & Sample size & Reference \\
\hline $\begin{array}{l}\text { CD44+/ } \\
\text { CD24- }\end{array}$ & $\begin{array}{l}\text { Fluorescent activated } \\
\text { cell sorting }\end{array}$ & $\begin{array}{l}\text { Patients with }>25 \% \text { CD44+/CD24- OC cells in ascites: } \\
\text { were more likely to reoccur ( } 83 \text { vs. } 14 \%, p=0.003 \text { ) } \\
\text { had shorter median PFS ( } 6 \text { vs. } 18 \mathrm{~m}, p=0.01 \text { ) }\end{array}$ & $\begin{array}{l}19 \text { ascites stage } \\
\text { IIIC/IV papillary } \\
\text { serous OC }\end{array}$ & {$[42]$} \\
\hline $\begin{array}{l}\mathrm{CD} 44+/ \\
\mathrm{CK} 19+\end{array}$ & $\begin{array}{l}\text { Tissue microarray } \\
\text { Immunofluorescent } \\
\text { staining }\end{array}$ & $\begin{array}{l}\text { High frequency of OC cells with CD44+ or CD } 44+/ C K 19+ \\
\text { associated with: } \\
\text { chemoresistance ( } p=0.033 \text { and } p=0.02 \text {, respectively) } \\
\text { High frequency of CD } 44+/ C K 19+\text { cells associated with: } \\
\text { short DFI ( } 7.9 \text { months vs. } 20.9 \text { months, } p=0.019) \\
\text { Significant predictor variables: } \\
\text { frequency of CSLCs ( } p=0.019) \\
\text { FIGO stage ( } p=0.037) \\
\text { residual tumor volume ( } p=0.005) \\
\text { The frequency of CSLCs=most promising predictor variable } \\
\text { (HR = 2.344, } p=0.052) \text {, but no independent significant } \\
\text { predictor found }\end{array}$ & $33 \mathrm{OC}$ & {$[9]$} \\
\hline CD44 & Tissue microarray & $\begin{array}{l}\text { Expression in } 38 \% \text { of cancers } \\
\text { Expression associated with: } \\
\text { high-grade carcinoma }(p=0.013) \\
\text { advanced stage FIGO }(I I I-I V ; p<0.001) \\
\text { age at diagnosis less than } 60 \text { years }(p=0.011) \\
\text { transitional cell carcinoma }(p=0.039) \\
\text { CD44 expression not associated with: } \\
\text { OS ( } p=0.529) \\
\text { DFS ( } p=0.218) \\
\text { No statistical difference in CD44 expression between the } \\
\text { primary and recurrent OC }\end{array}$ & $\begin{array}{l}27 \text { paired primary } \\
\text { and recurrent } O C\end{array}$ & {$[64]$} \\
\hline CD44 & Analysis of RNASeq data & CD44v8-10high = trend for longer survival. & $\begin{array}{l}254 \text { OC RNASeq } \\
\text { data }\end{array}$ & {$[65]$} \\
\hline CD44 & Immunohistochemistry & $\begin{array}{l}\text { CD44high protein expression correlated with increased survival } \\
(p=0.0181) \text { compared to those CD44low }(p=0.0262) \\
\text { CD44v8-10 presence: } \\
\text { in primary OC cell lines correlated with epithelial phenotype } \\
\text { in ascites ( } \text { proteolytically cleaved and soluble) extracellular } \\
\text { domain of CD44v8-10 correlated with worse prognosis } \\
(p<0.05)\end{array}$ & $\begin{array}{l}210 \text { high-grade } \\
\text { serous OC }\end{array}$ & {$[65]$} \\
\hline CD117 & Immunostaining & $\begin{array}{l}\text { Expression in } 40 \% \text { of cancers } \\
\text { Expression correlated with: } \\
\text { resistance to conventional chemotherapy }(p=0.027)\end{array}$ & $\begin{array}{l}25 \text { advanced } \\
\text { serous OC }\end{array}$ & {$[49]$} \\
\hline CD24 & Immunohistochemistry & $\begin{array}{l}\text { CD24 expression = independent predictor of survival, correlated } \\
\text { with: } \\
\text { FIGO stage } \\
\text { presence of peritoneal and lymph node metastasis }\end{array}$ & 174 primary OC & {$[67]$} \\
\hline
\end{tabular}

FIGO - International Federation of Gynecology and Obstetrics; high-grade serous ovarian cancer (HGSOC), primary (pOC) to recurrent (rOC)

\section{CD44/CD24}

The CD44+/CD24- population of OC cells displayed differentiation potential and drug resistance accompanied by higher invasion ability [41, 42].

The expression of the claudin-4 gene was significantly higher in CD44+ OC stem cells than CD44- cells [43]. Regardless of chemo-resistance, CD44+ cells could be targeted and destroyed, both in vitro and in vivo, by Clostridium perfringens enterotoxin (CPE) [43]. CD44 RNA was shown to be a target of miR-199 [44]. CD44 expression was shown in vitro to be associated with ALDH1, the expression of which was associated with short OS of patients. ALDH1 is reported to be an OC stem-like cell marker in association with CD44 [45].

\section{CD44/CD166}

The combination of high expression of CD44 and CD166 in OC cell lines indicated greater capacity for forming spheres and higher enzymatic activity of histone deacetylases, further implicating the role of epigenetic regulation in CSLC phenotype [46].

\section{CD117}

The proto-oncogene CD117, known also as c-kit, encodes a type 3 transmembrane receptor activated by stem cell factor (SCF). The interaction between both molecules has been thought to be involved in embryogenesis and carcinogenesis. Expression of c-kit in OC was confirmed 
Table 2. Surface markers on CSLCs: potential molecular targets on the ovarian cancer CSLCs

\begin{tabular}{|c|c|c|c|c|}
\hline $\begin{array}{l}\text { Target } \\
\text { molecules }\end{array}$ & Inhibitor & $\begin{array}{l}\text { Phenotype of } \\
\text { targeted cells }\end{array}$ & Effect & Reference \\
\hline ZEB2 & miR-200a & CD133/1+ & Reduction of cell migration and invasion & {$[23]$} \\
\hline MEK & U0126 & $\begin{array}{l}\text { Ovcar CD133+/ } \\
\text { CD44+/CD117+ }\end{array}$ & $\begin{array}{l}\text { Inhibition of ERK2 activation and partial suppression of cisplatin- } \\
\text { induced EMT and CSC markers' expression }\end{array}$ & {$[68]$} \\
\hline CXCR4 & AMD3100 & $\begin{array}{l}\text { NOY1 CD133+ } \\
\text { cells }\end{array}$ & $\begin{array}{l}\text { Inhibition of cell capacity of colony formation, migration and invasion } \\
\text { Inhibition of tumorigenicity in vivo }\end{array}$ & {$[26]$} \\
\hline $\begin{array}{l}\text { ETRA - } \\
\text { endothelin } \\
\text { receptor } A\end{array}$ & BQ123 & CD133+ & $\begin{array}{l}\text { Prevention of chemotherapy induced increases in tumor stem cells } \\
\text { ETRA inhibition + chemotherapy = reduced formation of tumor } \\
\text { spheres }\end{array}$ & {$[18]$} \\
\hline CD133 & $\begin{array}{l}\text { Anti-CD133 toxin } \\
\text { dCD133KDEL }\end{array}$ & $\mathrm{NIH}:$ OVCAR5 & $\begin{array}{l}\text { Inhibition of in vitro growth of } \mathrm{NIH} \text { :OVCAR5 cells. } \\
\text { Intraperitoneal drug therapy = decrease in tumor progression in } \\
\text { peritoneum }\end{array}$ & {$[19]$} \\
\hline CD44 & $\begin{array}{l}\text { nanoscale drug } \\
\text { delivery system } \\
\text { PI, paclitaxel } \\
\text { synthetic analog } \\
\text { of luteinizing } \\
\text { hormone-releasing } \\
\text { hormone }\end{array}$ & $\begin{array}{l}\text { Metastatic } \\
\text { CD44+ from } \\
\text { patient ascites }\end{array}$ & $\begin{array}{l}\text { Suppression of CD44 mRNA and protein, efficient induction of cell } \\
\text { death, effective tumor shrinkage, with prevention of adverse side } \\
\text { effects on healthy organs }\end{array}$ & {$[29]$} \\
\hline $\begin{array}{l}\text { Mullerian } \\
\text { substance }\end{array}$ & $\begin{array}{l}\text { Mullerian } \\
\text { inhibiting } \\
\text { substance-MIS } \\
\text { or its mimetic } \\
\text { SP600125 }\end{array}$ & $\begin{array}{l}\text { CD44+/CD24+/ } \\
\text { Epcam+ }\end{array}$ & $\begin{array}{l}\text { Shorter tumor-free intervals in vivo, enhanced migration in vitro. } \\
\text { Inhibition of CD44+/CD24+/Epcam+ cell growth (previously enhanced } \\
\text { by doxorubicin, cisplatin, and paclitaxel) }\end{array}$ & [39] \\
\hline CD44/EpCAM & $\begin{array}{l}\text { RNA-based } \\
\text { bispecific CD44 } \\
\text {-EpCAM aptamer }\end{array}$ & CD44+ cells & $\begin{array}{l}\text { Inhibition of cell growth and induction of apoptosis. } \\
\text { OC xenograft model: bispecific aptamer suppression of } \\
\text { intraperitoneal tumor outgrowth more efficient than single aptamers } \\
\text { or their combination. }\end{array}$ & {$[69]$} \\
\hline LIN28 & $\begin{array}{l}\text { MIS or MIS } \\
\text { mimetic SP600125 }\end{array}$ & $\begin{array}{l}\text { CD44+/CD24+/ } \\
\text { Epcam+/Ecad- }\end{array}$ & $\begin{array}{l}\text { Decreasing colony formation } \\
\text { Inhibition of OC cell growth by induction of G1 through cyclin- } \\
\text { dependent kinase inhibitors }\end{array}$ & {$[40]$} \\
\hline Mitochondria & $\begin{array}{l}\text { Isoflavone } \\
\text { derivative, NV-128 }\end{array}$ & $\begin{array}{l}\text { CD44+/MyD88+ } \\
\text { cells }\end{array}$ & $\begin{array}{l}\text { Depression of mitochondrial function and reduction of aggressive } \\
\text { phenotype }\end{array}$ & {$[35]$} \\
\hline CD44+ & $\begin{array}{l}\text { Conventional } \\
\text { therapy and fusion } \\
\text { cells }(C D+O C I C)\end{array}$ & cD44+ cells & $\begin{array}{l}\text { Activation of T cells to express elevated levels of IFN- } \gamma \text { with enhanced } \\
\text { killing of CD44+ OVCA cells }\end{array}$ & {$[30]$} \\
\hline Claudie-4 & $\begin{array}{l}\text { Clostridium } \\
\text { perfringens } \\
\text { enterotoxin (CPE) }\end{array}$ & cD44+ cells & $\begin{array}{l}\text { Intraperitoneal administration of sublethal doses of CPE in } \\
\text { mice harboring xenograft=significant inhibitory effect on tumor } \\
\text { progression: cure and/or long-term survival of all treated animals }\end{array}$ & {$[43]$} \\
\hline CD44 & miR-199a & $\begin{array}{l}\text { CD44+/CD117+ } \\
\text { OCICs }\end{array}$ & $\begin{array}{l}\text { Increase of chemosensitivity of ovarian CICs to cisplatin, paclitaxel, } \\
\text { Adriamycin; reduction of ABCG } 2 \text { and stemness markers' expression; } \\
\text { suppression of xenograft tumor growth }\end{array}$ & {$[44]$} \\
\hline $\begin{array}{l}\text { Survival- } \\
\text { promoting } \\
\text { mitochondria } \\
\text { complex of } \\
\text { hexokinase II } \\
\text { and VDAC }\end{array}$ & 3-bromopyruvate & $\begin{array}{l}\text { SKOV3 CD44+/ } \\
\text { CD117+/ALDH1+ } \\
\text { cells }\end{array}$ & $\begin{array}{l}\text { Sensitivity to combination treatment with significantly lowered doses } \\
\text { of cisplatin }\end{array}$ & {$[32]$} \\
\hline ETRA/ETRB & $\begin{array}{l}\text { Macitentan or } \\
\text { combination of } \\
\text { ETRA \& ETRB } \\
\text { antagonists BQ123 } \\
\text { \& BQ788 }\end{array}$ & CD133+ CSLCS & $\begin{array}{l}\text { No enhancement of antitumor immune cell recruitment. } \\
\text { In vitro prevention of ICAM } 1 \text { induction. } \\
\text { Prevention of chemotherapy-induced increases in tumor stem cells. } \\
\text { Macitentan alone= non-significant anti-tumor activity in vivo } \\
\text {-combined with chemotherapy= reduction of tumor growth (CD133+ } \\
\text { CSCs) combined with chemotherapy = reduction of sphere formation }\end{array}$ & {$[18]$} \\
\hline $\begin{array}{l}\text { IL-17 and its } \\
\text { downstream } \\
\text { pathways } \\
\text { NF-kB and p38 } \\
\text { MAPK signaling } \\
\text { pathways }\end{array}$ & $\begin{array}{l}\text { IL-17R-neutralizing } \\
\text { antibody } \\
\text { PDTC and } \\
\text { SB203580 }\end{array}$ & $\begin{array}{l}\text { CD133+ A2780 } \\
\text { cells }\end{array}$ & Sphere reduction & {$[21]$} \\
\hline
\end{tabular}


two decades ago $[47,48]$. Tumorigenic potential of CD117+ OC cells was confirmed in immunodeficient mice together with self-renewal and differentiation potential [49].

\section{CD24}

CD24 is a mucin-type adhesion molecule, associated with metastatic potential [50]. A CD24+ OC cell subpopulation was enriched in stem-like characteristics for self-renewal, differentiation, ability to recapitulate the tumor, chemo-resistance and expression of "stemness" genes [51]. CD24+ cells developed a tumor more efficiently than CD24- cells, a feature which was found before only for CD133+ cells [52]. CD24/CD117 association defines a cancer stem-like, chemo-resistant side population in ovary cancer [53].

\section{Clinical and prognostic relevance of surface markers}

Although CD133 was initially not linked to the clinical features or response to primary chemotherapy [12], a large study including 400 OC specimens showed that CD133 expression was associated with high-grade serous carcinoma, late-stage disease, ascites level, and lack of response to chemotherapy (Table 1). CD133 expression was also associated with shorter overall survival (OS) time and shorter disease-free survival (DFS) [54]. Multivariate analysis showed that CD133 is an independent predictor of shorter DFS [55]. CD133 (as opposed to CD44 and ALDH1) was the only marker of recurrent OC. The genes which were overexpressed in CD133+ recurrent cancer included members of the TGF- $\beta$ superfamily, Hedgehog, Notch and Wnt. Stem features appeared mostly after chemotherapy [56]. CD133 marked all TIC isolated from patients with serous OC, and although its frequency varies among patients its level is similar in primary OC and metastasis [57]. Nestin was found to be an independent prognostic factor for resistance to cisplatin and OS [58]. A meta-analysis of CD133 expression in OC showed that CD133 level correlates with tumor stage and its overexpression is highly linked to reduced 2-year OS [59].

Simultaneous expression of CD133 and ALDH1 identified cancer stem cells in OC. Expression of CD133 and ALDH1 is dependent on selection pressures such as starving, sphere culture and in vivo passaging [60]. Tumorigenicity of SKOV3 cells resides in the ALDH+/CD133+ population, which is 100 times more efficient than ALDH+/CD133-cells. The presence of ALDH+/CD133+ cells in primary OC specimens correlated with reduced DFS and OS [61]. High expression of ALDH1 was associated with shorter OS, CD44 expression, chemo-resistance, and poor clinical outcome, but this was not sufficient to define OC stem cells [45]. CD133 expression alone was characteristic for FIGO (International Federation of Gynecology and Obstetrics) stage III/IV patients and correlated with worse progression-free interval (PFI) and worse OS. Its coexpression with ALDH1 was an independent factor of PFI and OS [62]. Interestingly, oxidative stress induced by silver nanoparticles (AgNPs) was shown to be pro-apoptotic for ALDH1+/CD133+ cells, with Bcl-2 playing an important role in mitochondrial out- er membrane permeabilization and loss of mitochondrial membrane potential [63].

CD44 expression was associated with high-grade carcinoma and advanced FIGO stage, but not with OS or DFS. Moreover, expression levels of CD44 in the primary and recurrent ovarian carcinomas did not differ significantly [64]. CD44 isoforms studied on 254 tumor samples from The Cancer Genome Atlas RNAseqV2 showed a trend for longer survival in patients with high expression of the CD44V8-10 isoform. CD44v8-10 presence on the surface of primary tumor cells correlated with epithelial phenotype and better prognosis, whereas its soluble extracellular domain in ascitic fluid indicated worse prognosis [65]. OC CD44+/CD24OC phenotype correlated with increased recurrence and shorter progression-free survival (PFS) [42]. High frequency of CD44+ or CD44+/CD19+ cells was associated with chemo-resistance, whereas the combination of both markers indicated short disease-free interval (DFI) [9].

CD117 was present in 10 out of 25 OC, together with resistance to standard chemotherapeutics ( $p=0.007)$ [49]. A meta-analysis of selected CD117 studies showed the relation between CD117 status and several clinical parameters including: age, FIGO stage, tumor grade, histological type. High CD117 expression meant worse OS but no correlation with DFS was found [66].

Presence of CD24 expression was an independent predictor of survival and correlated with FIGO stage, peritoneal and lymph node metastases [67]

Results are hardly comparable due to the differences in the approaches and scoring methods, pointing to the need for large scale studies to conclude on the right combination of markers, the reliability of expression and pattern of relative levels of interactions.

\section{Conclusions}

Despite significant progress in experimental research so far it is still difficult to, it is still difficult to describe the surface phenotype of OC stem-like cells. The use of surface markers to identify CSLCS is helpful for better understanding of the resistance mechanisms in this gynecological malignancy, and in targeting CSLCS. As data remain fragmentary, the search for precise markers is ongoing. Well-defined recommendations for clinical application of surface markers on CSLC of OC still cannot be established. The four most probable stem-like cell markers of OC are CD133, CD44, CD24 and CD117 combined with the assessment of ALDH1 activity. Such an approach could enable us to distinguish different subpopulations of OC CSLCS, and define more precise molecular linking connecting the presence of surface markers to the stem-like phenotype of cancer cells.

Aleksandra Klemba and Cezary Szczylik have been supported by National Science Centre project 2012/07/N/ NZ5/02052. Claudine Kreda has been supported by Ministry of Defense Kościuszko I project 579/2016/DA. The authors declare no conflict of interest. Bogdan Lesyng acknowledges support of IMDiK PAN. 


\section{References}

1. Markowska J. Ovary. In: Gynecologic oncology. Elsevier Urban \& Partner, Wroclaw 2006; 945-965.

2. Permuth-Wey J, Sellers TA. Epidemiology of ovarian cancer. Methods Mol Biol 2009; 472: 413-437.

3. Agarwal R, Kaye SB. Expression profiling and individualisation of treatment for ovarian cancer. Current opinion in pharmacology 2006; 6: 345-349.

4. Chao SY, Chiang JH, Huang AM, Chang WS. An integrative approach to identifying cancer chemoresistance-associated pathways. BMC medical genomics 2011; 4: 23.

5. Bapat SA, Mali AM, Koppikar CB, Kurrey NK. Stem and progenitor-like cells contribute to the aggressive behavior of human epithelial ovarian cancer. Cancer Res 2005; 65: 3025-3029.

6. Bapat SA. Human ovarian cancer stem cells. Reproduction 2010; 140: 33-41.

7. Alvero $\mathrm{AB}$, Chen R, Fu HH, et al. Molecular phenotyping of human ovarian cancer stem cells unravels the mechanisms for repair and chemoresistance. Cell Cycle 2009; 8: 158-166.

8. Zhang S, Balch C, Chan MW, et al. Identification and characterization of ovarian cancer-initiating cells from primary human tumors. Cancer Res 2008; 68: 4311-4320.

9. Liu M, Mor G, Cheng $\mathrm{H}$, et al. High frequency of putative ovarian cancer stem cells with CD44/CK19 coexpression is associated with decreased progression-free intervals in patients with recurrent epithelial ovarian cancer. Reprod Sci 2013; 20: 605-615.

10. Yin AH, Miraglia S, Zanjani ED, et al. AC133, a novel marker for human hematopoietic stem and progenitor cells. Blood 1997; 90: 5002-5012.

11. Jang JW, Song Y, Kim SH, et al. Potential mechanisms of CD133 in cancer stem cells. Life Sci 2017; 184: 25-29.

12. Ferrandina G, Bonanno G, Pierelli L, et al. Expression of CD133-1 and CD133-2 in ovarian cancer. Int J Gynecol Cancer 2008; 18: 506514.

13. Ferrandina G, Martinelli E, Petrillo M, et al. CD133 antigen expres sion in ovarian cancer. BMC Cancer 2009; 9: 221.

14. Curley MD, Therrien VA, Cummings CL, et al. CD133 expression defines a tumor initiating cell population in primary human ovarian cancer. Stem Cells 2009; 27: 2875-2883.

15. Baba T, Convery PA, Matsumura N, et al. Epigenetic regulation of CD133 and tumorigenicity of CD133+ ovarian cancer cells. Oncogene 2009; 28: 209-218.

16. Min KJ, So KA, Ouh YT, et al. The effects of DNA methylation and epigenetic factors on the expression of CD133 in ovarian cancers. J Ovarian Res 2012; 5: 28.

17. Ponnusamy MP, Seshacharyulu P, Vaz A, et al. MUC4 stabilizes HER2 expression and maintains the cancer stem cell population in ovarian cancer cells. J Ovarian Res 2011; $4: 7$.

18. Coffman L, Mooney C, Lim J, et al. Endothelin receptor-A is required for the recruitment of antitumor T cells and modulates chemotherapy induction of cancer stem cells. Cancer Biol Ther 2013; 14: 184-192.

19. Skubitz AP, Taras EP, Boylan KL, et al. Targeting CD133 in an in vivo ovarian cancer model reduces ovarian cancer progression. Gynecol Oncol 2013; 130: 579-587.

20. Long $H$, Xie R, Xiang $T$, et al. Autocrine CCL5 signaling promotes invasion and migration of CD133+ ovarian cancer stem-like cells via NF-kappaB-mediated MMP-9 upregulation. Stem Cells 2012; 30: 2309-2319

21. Xiang T, Long H, He L, et al. Interleukin-17 produced by tumor microenvironment promotes self-renewal of CD133+ cancer stemlike cells in ovarian cancer. Oncogene 2015; 34: 165-176.

22. Guo R, Wu Q, Liu F, Wang Y. Description of the CD133+ subpopulation of the human ovarian cancer cell line OVCAR3. Oncol Rep 2011; 25: 141-146.

23. Wu Q, Guo R, Lin M, et al. MicroRNA-200a inhibits CD133/1+ ovarian cancer stem cells migration and invasion by targeting E-cadherin repressor ZEB2. Gynecol Oncol 2011; 122: 149-154.

24. Nam EJ, Lee M, Yim GW, et al. MicroRNA profiling of a CD133(+) spheroid-forming subpopulation of the OVCAR3 human ovarian cancer cell line. BMC Med Genomics 2012; 5: 18.
25. Suzuki S, Terauchi M, Umezu T, et al. Identification and characterization of cancer stem cells in ovarian yolk sac tumors. Cancer Sci 2010; 101: 2179-2185.

26. Mitsui H, Shibata K, Suzuki S, et al. Functional interaction between peritoneal mesothelial cells and stem cells of ovarian yolk sac tumor (SC-OYST) in peritoneal dissemination. Gynecol Oncol 2012; 124: 303-310.

27. Shtivelman E, Bishop JM. Expression of CD44 is repressed in neu roblastoma cells. Mol Cell Biol 1991; 11: 5446-5453.

28. Bourguignon LY, Peyrollier K, Xia W, Gilad E. Hyaluronan-CD44 interaction activates stem cell marker Nanog, Stat-3-mediated MDR1 gene expression, and ankyrin-regulated multidrug efflux in breast and ovarian tumor cells. J Biol Chem 2008; 283: 17635 17651.

29. Shah V, Taratula O, Garbuzenko OB, et al. Targeted Nanomedicine for Suppression of CD44 and Simultaneous Cell Death Induction in Ovarian Cancer: An Optimal Delivery of siRNA and Anticancer Drug. Clin Cancer Res 2013; 19: 6193-6204

30. Weng D, Song B, Durfee J, et al. Induction of cytotoxic T lymphocytes against ovarian cancer-initiating cells. Int J Cancer 2011; 129: 1990-2001.

31. Cao L, Shao M, Schilder J, et al. Tissue transglutaminase links TGF-beta, epithelial to mesenchymal transition and a stem cell phenotype in ovarian cancer. Oncogene 2012; 31: 2521-2534.

32. Wintzell M, Lofstedt L, Johansson J, et al. Repeated cisplatin treatment can lead to a multiresistant tumor cell population with stem cell features and sensitivity to 3-bromopyruvate. Cancer Biol Ther 2012; 13: 1454-1462.

33. Chen D, Zhang Y, Wang J, et al. MicroRNA-200c overexpression inhibits tumorigenicity and metastasis of CD117+CD44+ ovarian cancer stem cells by regulating epithelial-mesenchymal transition. J Ovarian Res 2013; 6: 50.

34. Li Z, Block MS, Vierkant RA, et al. The inflammatory microenvironment in epithelial ovarian cancer: a role for TLR4 and MyD88 and related proteins. Tumour Biol 2016; 37: 13279-13286.

35. Alvero AB, Montagna MK, Holmberg JC, et al. Targeting the mitochondria activates two independent cell death pathways in ovarian cancer stem cells. Mol Cancer Ther 2011; 10: 1385-1393.

36. Chefetz I, Alvero AB, Holmberg JC, et al. TLR2 enhances ovarian cancer stem cell self-renewal and promotes tumor repair and recurrence. Cell Cycle 2013; 12: 511-521.

37. Alvero AB, Fu HH, Holmberg J, et al. Stem-like ovarian cancer cells can serve as tumor vascular progenitors. Stem Cells 2009; 27: 2405-2413

38. Yin G, Alvero AB, Craveiro V, et al. Constitutive proteasomal degradation of TWIST-1 in epithelial-ovarian cancer stem cells impacts differentiation and metastatic potential. Oncogene 2013; 32: 39-49.

39. Wei X, Dombkowski D, Meirelles K, et al. Mullerian inhibiting substance preferentially inhibits stem/progenitors in human ovarian cancer cell lines compared with chemotherapeutics. Proc Nat Acad Sci U S A 2010; 107: 18874-18879.

40. Meirelles K, Benedict LA, Dombkowski D, et al. Human ovarian cancer stem/progenitor cells are stimulated by doxorubicin but inhibited by Mullerian inhibiting substance. Proc Natl Acad Sci U S A 2012; 109: 2358-2363.

41. Shi MF, Jiao J, Lu WG, et al. Identification of cancer stem cell-like cells from human epithelial ovarian carcinoma cell line. Cell Mo Life Sci 2010; 67: 3915-3925.

42. Meng E, Long B, Sullivan P, et al. CD44+/CD24- ovarian cancer cells demonstrate cancer stem cell properties and correlate to survival. Clin Exp Metastasis 2012; 29: 939-948.

43. Casagrande F, Cocco E, Bellone S, et al. Eradication of chemotherapy-resistant CD44+ human ovarian cancer stem cells in mice by intraperitoneal administration of Clostridium perfringens enterotoxin. Cancer 2011; 117: 5519-5528.

44. Cheng W, Liu T, Wan X, et al. MicroRNA-199a targets CD44 to suppress the tumorigenicity and multidrug resistance of ovarian cancer-initiating cells. Febs j 2012; 279: 2047-2059.

45. Wang YC, Yo YT, Lee HY, et al. ALDH1-bright epithelial ovarian cancer cells are associated with CD44 expression, drug resistance, and poor clinical outcome. Am J Pathol 2012; 180: 1159-1169. 
46. Witt $A E$, Lee CW, Lee $T$, et al. Identification of a cancer stem cell-specific function for the histone deacetylases, HDAC1 and HDAC7, in breast and ovarian cancer. Oncogene 2017; 36: 17071720.

47. Inoue M, Kyo S, Fujita M, et al. Coexpression of the c-kit receptor and the stem cell factor in gynecological tumors. Cancer Res 1994 54: 3049-3053.

48. Miettinen M, Lasota J. KIT (CD117): a review on expression in nor mal and neoplastic tissues, and mutations and their clinicopathologic correlation. Appl Immunohistochem Mol Morphol 2005; 13: 205-220.

49. Luo L, Zeng J, Liang B, et al. Ovarian cancer cells with the CD117 phenotype are highly tumorigenic and are related to chemotherapy outcome. Exp Mol Pathol 2011; 91: 596-602.

50. Lim SC. CD24 and human carcinoma: tumor biological aspects. Biomed Pharmacother 2005; 59 Suppl 2: S351-354.

51. Gao MQ, Choi YP, Kang S, et al. CD24+ cells from hierarchically organized ovarian cancer are enriched in cancer stem cells. Oncogene 2010; 29: 2672-2680.

52. Burgos-Ojeda D, McLean K, Bai S, et al. A novel model for evaluating therapies targeting human tumor vasculature and human cancer stem-like cells. Cancer Res 2013; 73: 3555-3565.

53. Choi YP, Shim HS, Gao MO, et al. Molecular portraits of intratumoral heterogeneity in human ovarian cancer. Cancer Lett 2011; 307: 62-71.

54. Stemberger-Papic S, Vrdoljak-Mozetic D, Ostojic DV, et al. Expression of CD133 and CD117 in 64 Serous Ovarian Cancer Cases. Coll Antropol 2015; 39: 745-753.

55. Zhang J, Guo X, Chang DY, et al. CD133 expression associated with poor prognosis in ovarian cancer. Mod Pathol 2012; 25: 456-464.

56. Steg AD, Bevis KS, Katre AA, et al. Stem cell pathways contribute to clinical chemoresistance in ovarian cancer. Clin Cancer Res 2012; 18: 869-881

57. Stewart JM, Shaw PA, Gedye C, et al. Phenotypic heterogeneity and instability of human ovarian tumor-initiating cells. Proc Natl Acad Sci U S A 2011; 108: 6468-6473.

58. Qin Q, Sun Y, Fei M, et al. Expression of putative stem marker nestin and CD133 in advanced serous ovarian cancer. Neoplasma 2012; 59: 310-315.

59. Zhou Q, Chen A, Song H, et al. Prognostic value of cancer stem cell marker CD133 in ovarian cancer: a meta-analysis. Int J Clin Exp Med 2015; 8: 3080-3088.

60. Kryczek I, Liu S, Roh M, et al. Expression of aldehyde dehydrogenase and CD133 defines ovarian cancer stem cells. Int J Cancer 2012; 130: 29-39.

61. Silva IA, Bai S, McLean K, et al. Aldehyde dehydrogenase in combination with CD133 defines angiogenic ovarian cancer stem cells that portend poor patient survival. Cancer Res 2011; 71: 3991-4001.

62. Ruscito I, Cacsire Castillo-Tong D, Vergote I, et al. Exploring the clonal evolution of CD133/aldehyde-dehydrogenase-1 (ALDH1)-positive cancer stem-like cells from primary to recurrent high-grade serous ovarian cancer (HGSOC). A study of the Ovarian Cancer Therapy-Innovative Models Prolong Survival (OCTIPS) Consortium. Eur J Cancer 2017; 79: 214-225.

63. Choi YJ, Park JH, Han JW, et al. Differential Cytotoxic Potential of Silver Nanoparticles in Human Ovarian Cancer Cells and Ovarian Cancer Stem Cells. Int J Mol Sci 2016; 17: 2077.

64. Zhang J, Chang B, Liu J. CD44 standard form expression is correlated with high-grade and advanced-stage ovarian carcinoma but not prognosis. Hum Pathol 2013; 44: 1882-1889.

65. Sosulski A, Horn H, Zhang L, et al. CD44 Splice Variant v8-10 as a Marker of Serous Ovarian Cancer Prognosis. PLoS One 2016; 11 e0156595.

66. Yang B, Yan X, Liu L, et al. Overexpression of the cancer stem cell marker CD117 predicts poor prognosis in epithelial ovarian cancer patients: evidence from meta-analysis. Onco Targets Ther 2017; 10: 2951-2961

67. Nakamura K, Terai Y, Tanabe A, et al. CD24 expression is a marker for predicting clinical outcome and regulates the epithelial-mesenchymal transition in ovarian cancer via both the Akt and ERK pathways. Oncol Rep 2017; 37: 3189-3200.
68. Latifi A, Abubaker K, Castrechini N, et al. Cisplatin treatment of primary and metastatic epithelial ovarian carcinomas generates residual cells with mesenchymal stem cell-like profile. J Cell Biochem 2011; 112: 2850-2864.

69. Zheng J, Zhao S, Yu X, et al. Simultaneous targeting of CD44 and EpCAM with a bispecific aptamer effectively inhibits intraperitoneal ovarian cancer growth. Theranostics 2017; 7: 1373-1388.

\section{Address for correspondence}

\section{Aleksandra Klemba}

Laboratory of Molecular Oncology

Department of Oncology

Military Institute of Medicine

Szaserów 128

04-141 Warsaw, Poland

tel. +48 226817172

$\mathrm{fax}+48226103098$

e-mail: aklemba@wim.mil.pl 